\title{
Enteric Viruses
}

\author{
C. Anthony Hart, Nigel A. Cunliffe
}

\section{Introduction}

Viruses interact with the gastro-intestinal tract in a number of ways. Some viruses such as hepatitis A virus and the enteroviruses use the intestine as a portal of entry and rarely, if ever, produce diarrhoeal disease. Others cause diarrhoeal disease only when the immune system is compromised, for example, $\mathrm{HIV}$ and cytomegalovirus (HHV-5). Human papillomaviruses and Kaposi's sarcoma associated herpesvirus (HHV-8) can affect the gastro-intestinal tract causing local tumours. On stool electron microscopy, bacteriophages can be seen (Fig. 1) which can be mistaken for other viruses. Bacteriophages are viruses that infect bacteria and are involved only indirectly in human disease, for example, acting as vectors for toxin genes (e.g. shiga toxins 1 and 2 in Escherichia coli 0157). However, here we will concentrate on the virology and laboratory diagnosis of the enteric viruses that are primary pathogens causing diarrhoeal disease (Table 1). The relative importance of viruses and the various enteric viruses depends upon the patient's age and their state of immunity. Undoubtedly, viruses are the most important causes of diarrhoeal disease in infants and young children whether HIV-infected or not [1].

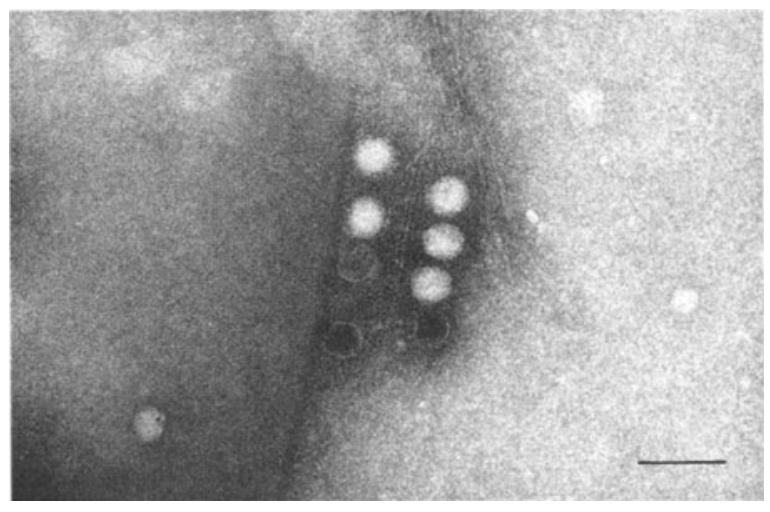

Fig. 1. Bacteriophage particles can easily be misidentified as potential viral enteropathogens. Bar, $100 \mathrm{~nm}$

Table 1. The enteric viral enteropathogens

\begin{tabular}{|c|c|c|c|c|c|}
\hline & Genome & Size & $\begin{array}{l}\text { Relative } \\
\text { importance } \\
\text { in children }\end{array}$ & $\begin{array}{l}\text { Relative } \\
\text { importance } \\
\text { in adults }\end{array}$ & $\begin{array}{l}\text { Causes } \\
\text { outbreaks }\end{array}$ \\
\hline Rotavirus & dsRNA, linear segmented & $80 \mathrm{~nm}$ & ++++ & + & + \\
\hline Adenovirus & DNA, linear & $80 \mathrm{~nm}$ & ++ & + & - \\
\hline Astrovirus & ssRNA, linear positive-sense & $28-34 \mathrm{~nm}$ & ++ & + & + \\
\hline \multicolumn{6}{|l|}{ Calicivirus } \\
\hline Norwalk-like & ssRNA, linear, positive-sense & $28-32 \mathrm{~nm}$ & ++ & + & + \\
\hline Sapporo-like & ssRNA, linear positive-sense & $28-32 \mathrm{~nm}$ & ++ & ++ & + \\
\hline Coronavirus & ssRNA, linear, positive-sense & $60-200 \mathrm{~nm}$ & + & $?$ & $?$ \\
\hline Torovirus & ssRNA, linear, positive-sense & $100-140 \mathrm{~nm}$ & + & $?$ & $?$ \\
\hline Picobirnavirus & dsRNA, linear, segmented & $40-50 \mathrm{~nm}$ & + & $?$ & $?$ \\
\hline Pestivirus & ssRNA, linear, positive-sense & $45-55 \mathrm{~nm}$ & + & $?$ & $?$ \\
\hline
\end{tabular}




\section{Rotavirus}

Human rotavirus was first described as a human pathogen in 1973, when Ruth Bishop and colleagues observed virus particles, which they named duovirus, on thin-section electron microscopy of duodenal biopsy specimens from an infant with acute watery diarrhoea [2]. Subsequently, it was found that virus could be easily detected by negative stain electron microscopy of faeces. The virus was re-named rotavirus because of its characteristic wheel-shaped (rota is Latin for a wheel) morphology (Fig. 2).

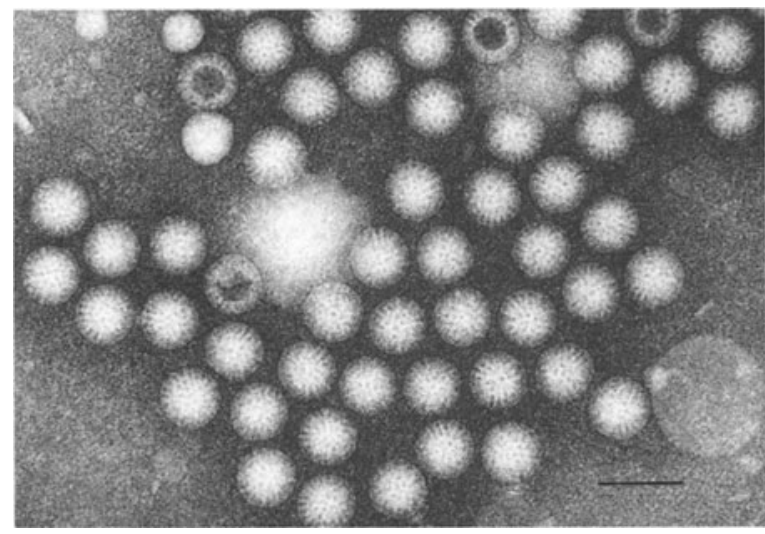

Fig. 2. A negative stain electron micrograph of faeces showing a cluster of rotavirus particles. Bar, $100 \mathrm{~nm}$

\section{Virology}

Rotavirus is a member of the family Reoviridae and has a double-stranded segmented RNA genome. There are 11 genomic segments and each encodes one or more polypeptides (Table 2). It is $75-80 \mathrm{~nm}$ in diameter with a characteristic double-shelled capsid that gives it a wheel-shaped appearance. The core of the virus contains VP (virus proteins) 1, 2 and 3 and the 11 genomic segments. The inner capsid is composed entirely of VP6 and the outer capsid is composed of $\mathrm{VP}_{4}$ and $\mathrm{VP}_{7}$ (Fig. 3). The remaining proteins are involved in replication and are found only

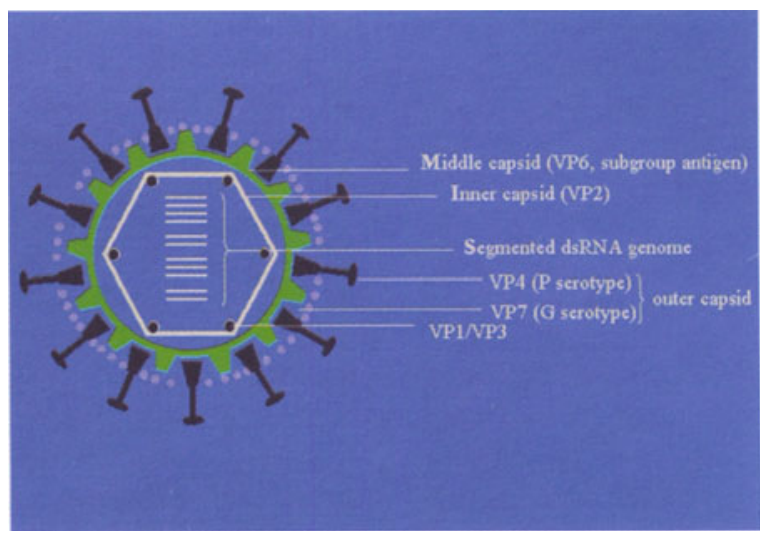

Fig. 3. A cartoon showing the structural proteins and genome of rotavirus

Table 2. Rotavirus genome and gene products

\begin{tabular}{|c|c|c|c|c|c|}
\hline $\begin{array}{l}\text { Genome } \\
\text { segment }\end{array}$ & $\begin{array}{l}\text { Molecular } \\
\text { size (bp) }\end{array}$ & $\begin{array}{l}\text { Gene } \\
\text { product }\end{array}$ & $\begin{array}{l}\text { Molecular } \\
\text { weight } \\
\text { (kDa) }\end{array}$ & $\begin{array}{l}\text { Location in } \\
\text { virion }\end{array}$ & Function \\
\hline 1 & 3,302 & VP1 & 125 & Core & RNA polymerase \\
\hline 2 & 2,690 & $\mathrm{VP}_{2}$ & 94 & Core & RNA binding \\
\hline 3 & 2,591 & $\mathrm{VP}_{3}$ & 88 & Core & Guanylytransferase \\
\hline 4 & 2,362 & $\begin{array}{l}\mathrm{VP}_{4} \\
\left(\mathrm{VP}_{5}^{*}+\mathrm{VP}^{*}\right)\end{array}$ & $88^{\mathrm{a}}$ & Outer capsid & $\begin{array}{l}\text { Cell attachment and penetration; } \\
\text { Haemagglutinin; } \\
\text { neutralizing antigen [P-(protease } \\
\text { sensitive) serotype] }\end{array}$ \\
\hline 5 & 1,581 & NSP1 & 53 & Non-structural & RNA binding (zinc finger) \\
\hline 6 & 1,356 & VP6 & 41 & Inner capsid & Group and subgroup antigen \\
\hline 7 & 1,104 & $\mathrm{NSP}_{3}$ & 34 & Non-structural & RNA binding \\
\hline 8 & 1,059 & $\mathrm{NSP}_{2}$ & 35 & Non-structural & RNA binding \\
\hline 9 & 1,062 & $\mathrm{VP}_{7}$ & 38 & Outer capsid & $\begin{array}{l}\text { Neutralizing antigen } \\
\text { [G-(glycoprotein)-serotype] }\end{array}$ \\
\hline 10 & 751 & $\mathrm{NSP}_{4}$ & 28 & Non-structural & Virus assembly; enterotoxin \\
\hline 11 & 667 & $\mathrm{NSP}_{5}$ & 26 & Non-structural & RNA binding \\
\hline
\end{tabular}

${ }^{a}$ Virus protein (VP) 4 must be cleaved into $\mathrm{VP}^{*}$ and $\mathrm{VP} 8^{*}$ by proteolysis for full infectivity. 
in infected cells and are thus termed NSP (non-structural proteins) of which there are 5 (NSP1-5). $\mathrm{VP}_{4}$ $\left(\mathrm{VP}_{5}{ }^{*}, \mathrm{VP}^{*}\right)$ and $\mathrm{VP}_{7}$ are involved in attachment to and penetration into host enterocytes. These outer capsid proteins carry neutralising epitopes, and antibody to these epitopes confers immunity to infection. There is still debate over whether the inner capsid protein VP6 carries neutralising epitopes [3].

\section{Epidemiological Markers and Diversity}

Rotavirus can be subdivided into one of seven groups $(A-G)$ by epitopes on VP6. However, humans are infectable only by groups A, B and C. Of these, group $A$ rotaviruses are the most important, and all people will have experienced recurrent group A rotavirus infections throughout their lifetime. Approximately $30 \%$ of adults have serological evidence of group C rotavirus infection [4]. However, in a survey of childhood diarrhoea in Malawi, only $3.3 \%$ of children were found to have group $\mathrm{C}$ rotavirus infection and almost two-thirds of these were co-infected with group $\mathrm{A}$ rotaviruses [5]. Group B rotaviruses have been responsible for large outbreaks of diarrhoeal disease in adults and children in China and India [6]. Rotaviruses can also infect a large number of animal species, for example, group A rotaviruses can cause infection in primates, cattle, pigs, sheep, horses, dogs, cats and turkeys. It was thought that the viruses were species-specific but there is increasing evidence of cross-species transmission. Group A rotaviruses can be further subdivided into subgroups, again, on the basis of epitopes on VP6. They can have subgroup specificities I, II, I + II or neither. Group A rotaviruses can also be serotyped and there are two major antigenic types. These are G (or glycoprotein) types expressed on the outer capsid protein $\mathrm{VP} 7$ of which there are at least 14 types. The $\mathrm{P}$ (or protease sensitive) serotypes are encoded on $\mathrm{VP}_{4}$ $\left(\mathrm{VP}_{5}^{*}, \mathrm{VP} 8^{*}\right)$; there are at least $20 \mathrm{P}$ types. Antibody to a particular $P$ or $G$ type does not necessarily confer immunity to the others. $G$ and $P$ types were originally delineated by using monoclonal antibodies that neutralised rotavirus growth. However, this required establishing the rotavirus in artificial culture which is not a trivial task and then determining neutralising antibody activity. To overcome this, RT-PCR-based techniques have been developed for P and G typing (Fig. 4). Thus far, all the $G$ serotypes and $G$ genotypes have coincided. Unfortunately, this has not been established for all the $\mathrm{P}$ serotypes and $\mathrm{P}$ genotypes, thus by convention $\mathrm{P}$ serotypes are indicated by rounded brackets, e.g. $\mathrm{P}(3 \mathrm{a})$ and $\mathrm{P}$ genotypes by squared brackets, e.g. P [8]. Variability in the molecular mass of the 11 genomic sequences (as deter-

Fig. 4a, b Primers for detection and G- and P- genotyping rotavirus by RT-PCR.

a Primers used for $\mathrm{VP}_{7}(\mathrm{G})$ typing

\begin{tabular}{lllllll}
\hline Primer & Strain & Serotype & NT & Sense & Sequence (5` to 3`) & Primer type \\
\hline 9Con1 & Wa & G1 & $37-56$ & + & TAG CTC CTT TTA ATG TAT GG & Consensus \\
9Con2 & Wa & G1 & $922-941$ & - & GTA TAA AAT ACT TGC CAC CA & Consensus \\
9T-1 & Wa & G1 & $176-195$ & - & TCT TGT CAA AGC AAA TAA TG & Type Specific \\
9T-2 & S2 & G2 & $262-281$ & - & GTT AGA AAT GAT TCT CCA CT & Type Specific \\
9T-3P & $107 E$ & G3 & $484-503$ & - & GTC CAG TTG CAG TGT TAG C & Type Specific \\
9T-4 & ST 3 & G4 & $423-440$ & - & GGG TCG ATG GAA AAT TCT & Type Specific \\
106 & HMG89 & G8 & $681-697$ & - & TCT TCA AAA GTC GTA GTG & Type Specific \\
9T-9B & $116 \mathrm{E}$ & $\mathrm{G} 9$ & $131-147$ & - & TAT AAA GTC CAT TGC AC & Type Specific \\
\hline
\end{tabular}

\begin{tabular}{|c|c|c|c|c|c|}
\hline \multicolumn{5}{|l|}{$\begin{array}{l}9 \text { Conn } \rightarrow \\
5^{\wedge} 1\end{array}$} & $\begin{array}{r}\leftarrow 9 \text { Con2 } \\
-10623\end{array}$ \\
\hline$\stackrel{\leftarrow}{9 \mathrm{~T}-9 \mathrm{~B}}$ & $\leftarrow \underset{9 \mathrm{~T}-1}{\leftarrow}$ & $\leftarrow \leftarrow$ & 9T-4 & $9 \mathrm{~T}-3 \mathrm{P}$ & 106 \\
\hline
\end{tabular}

$111 \mathrm{bp}$

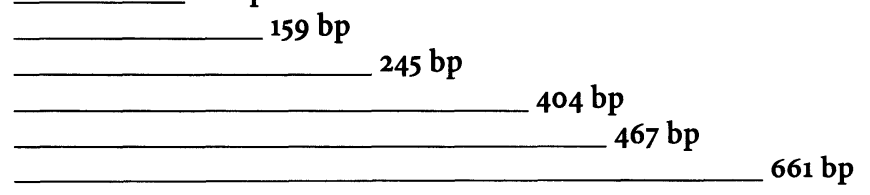


b Primers used for $\mathrm{VP}_{4}(\mathrm{P})$ typing

\begin{tabular}{lllllll}
\hline Primer & Strain & Serotype $([\mathbf{G T}])$ & NT & Sense & Sequence $\left(5^{`}\right.$ to $\left.3^{`}\right)$ & Primer type \\
\hline Con3 & $\mathrm{Ku}$ & $1 \mathrm{~A}[8]$ & $11-32$ & + & TGG CTT CGC CAT TTT ATA GAC A Consensus \\
Con 2 & $\mathrm{Ku}$ & $1 \mathrm{~A}[8]$ & $868-887$ & - & ATT TCG GAC CAT TTA TAA CC & Consensus \\
$1 \mathrm{~T}-1$ & $\mathrm{Ku}$ & $1 \mathrm{~A}[8]$ & $339-356$ & - & TCT ACT TGG ATA ACG TGC & Type Specific \\
$2 \mathrm{~T}-1$ & $\mathrm{RV} 5$ & $1 \mathrm{~B}[4]$ & $474-494$ & - & CTA TTG TTA GAG GTT AGA GTC & Type Specific \\
$3 \mathrm{~T}-1$ & 1076 & $2 \mathrm{~A}[6]$ & $259-278$ & - & TGT TGA TTA GTT GGA TTC AA & Type Specific \\
$4 \mathrm{~T}-1$ & $\mathrm{~K} 8$ & $3[9]$ & $385-402$ & - & TGA GAC ATG CAA TTG GAC & Type Specific \\
$5 \mathrm{~T}-1$ & $69 \mathrm{M}$ & $4[10]$ & $575-594$ & - & ATC ATA GTT AGT AGT CGG & Type Specific \\
\hline
\end{tabular}

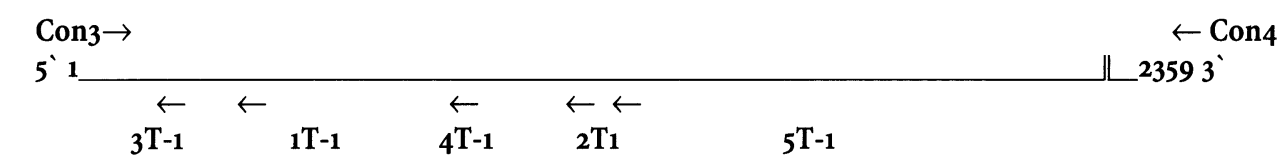

877 bp

$568 \mathrm{bp}$

$346 \mathrm{bp}$

$392 \mathrm{bp}$

$484 \mathrm{bp}$

$584 \mathrm{bp}$

mined by gel electrophoresis) can also be used to type rotaviruses. In particular the rate of migration of the lowest molecular weight segments (in particular segment 11) splits rotavirus into long, short and super-short electropherotypes. In addition, comparison of the patterns of migration of all the genomic segments when co-electrophoresed can also give evidence of relatedness or otherwise (Fig. 5). Despite this plethora of grouping and typing methods, group A rotaviruses can generally be subdivided into two major genogroups named Wa and DS-1 after their prototype isolates. Members of each genogroup possess particular sets of electropherotype, subgroup and $\mathrm{P}$ and $\mathrm{G}$ type. The Wa genogroups are predominantly long electropherotype, sub group II with $\mathrm{VP}_{4}$ $\mathrm{P}[6]$ or $\mathrm{P}[8]$ and $\mathrm{VP}_{7} \mathrm{G} 1,3$ or 4 serotypes. DS-1 genogroup rotaviruses are generally of short electropherotype, subgroup I and $\mathrm{P}[4]$ and $\mathrm{G}_{2}$ serotype specificity. However, this neat segregation is proving to be less than absolute [7]. Because rotaviruses have a segmented genome, novel genogroups can, and have, emerged by re-assortment (exchange of genomic segments in whole or partially when two rotaviruses co-infect the same cell). Novel humanfeline, human-canine and human-bovine rotaviruses have been described. In addition, antigenic drift also occurs when point mutations accumulate. Thus there is evidence of a greatly increasing diversity of rotaviruses. Previously, examination of global collections of rotaviruses demonstrated that serotypes $\mathrm{G} 1$ to $\mathrm{G}_{4}$ accounted for the vast majority of human infections ( $80 \%-90 \%$ of strains) [8]. Recently, novel strains including G5 in South America, G8 in Malawi, South Africa and Nigeria and G9 have emerged [9-12]. Indeed, G9 is a globally important serotype being detected in almost every country it has been sought $[12,13]$.

Rotavirus is the commonest cause of acute dehydrating watery diarrhoea in infants worldwide. It is

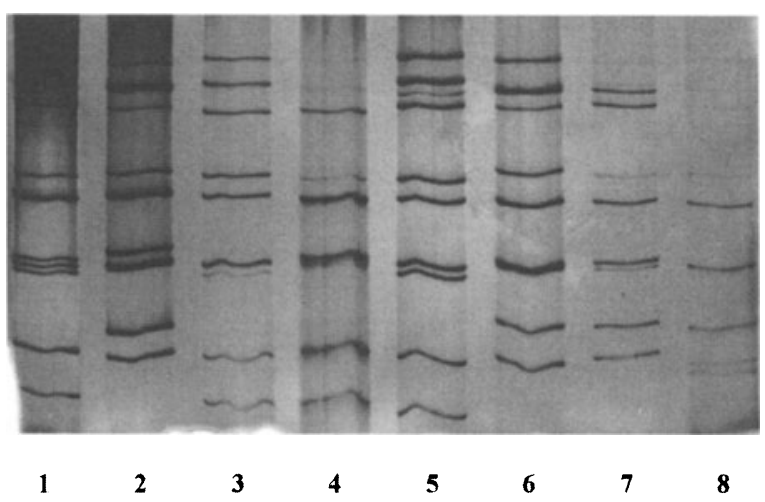

Fig. 5. Polyacrylamide gel electrophorograms of rotavirus dsRNA from faeces

Lanes 1-2: Standard strains showing long electropherotype profile (strain $\mathrm{Wa}$, lane 1 ), and short electropherotype profile (strain DS-1, lane 2)

Lanes 3-7: Malawi field strains showing long electropherotype profiles (lanes 3-5), and short electropherotype profiles (lanes 6-7)

Lane 8: Malawi field strain showing mixed short electropherotype profile 
responsible for $20 \%-60 \%$ of cases of infantile diarrhoea in both hospital and community-based surveys [1]. It is estimated to be responsible for between 500,000 and 800,000 deaths each year in children under 5 years and most (but not all) of these deaths are in developing countries [14]. In temperate countries, there are peaks of infection in the winter months. In sub-Saharan Africa, infection is prevalent throughout the year but with a peak in the dry season [15]. Although most infections present in infants, infections do occur in adults, for example, with group B rotavirus or unusual group A serotypes. It is also a cause of travellers' diarrhoea.

\section{Pathogenesis and Immunity}

Rotavirus is transmitted predominantly by the faecooral route although there are some indications of spread by the air-borne route. An infected child can excrete up to $10^{11}$ rotavirus particles per millilitre of faeces and the infective dose is as low as $10^{2}$ particles. Rotavirus infects the whole of the small intestine but cannot infect colonocytes. It infects mature villous body enterocytes but cannot infect immature crypt enterocytes. At least four mechanisms have been suggested by which rotavirus causes diarrhoea. Firstly, the disaccharidase enzymes lactase, sucrase and maltase are essential for absorption of sugars. If disaccharides are not cleaved to monosaccharides by these enzymes then they cannot be absorbed, remain in the gut lumen and induce an osmotic diarrhoea. The disaccharidase enzymes are integral proteins in the microvillar membranes. They have a short half-life and are continually replaced by new enzymes synthesised in the enterocyte. Rotavirus appears to interfere with the trafficking of newly synthesised disaccharidases from the Golgi to the microvilli thus leading to a relative disaccharidase deficiency $[16,17]$. Secondly, on maturation, rotavirus kills infected enterocytes by oncosis [18]. This leads to a higher rate of death of enterocytes which cannot be replaced quickly enough, and villous blunting occurs leading to a loss of absorptive surface area. Thirdly, there are suggestions that rotavirus affects the intestinal neuroendocrine axis [19]. Finally, recent experiments have delineated the first viral toxin to be described [20]. NSP-4 is involved in viral capsid assembly and entry into endosomes. However, it also has an effect similar to that of cholera toxin in causing a secretory diarrhoea. In immunocompetent children, rotavirus diarrhoea persists for an average of 6-7 days. It appears that cell-mediated immunity is important in resolution of the acute infection [21] and it is noteworthy that children with T-cell deficits exhibit longterm excretion of rotavirus. In general, one infection with rotavirus confers protection against symptomatic re-infection but not silent re-infection [22]. Whether this is true for HIV-infected infants is not known. The role of individual components in immunity is also not entirely clear but the best surrogates of immunity appear to be IgA antirotavirus coproantibodies and serum IgG anti-rotavirus antibody [23].

\section{Laboratory Diagnosis}

A patient with acute watery diarrhoea due to rotavirus excretes large numbers of virus particles (ca. $10^{11} / \mathrm{ml}$ ). These are easily seen and because of their characteristic shape and size recognised on direct negative stain electron microscopy of stool (Fig. 2). Electron microscopy is the only "catch-all" technique for the diagnosis of infection by rotavirus or other enteric viruses, but is limited by sensitivity (it requires in the order of $10^{5}$ particles $/ \mathrm{ml}$ ) and the skill of the electron microscopist. The pathogen-specific diagnostic tests for rotavirus include methods for genome and antigen detection. Virus culture is not a feasible routine diagnostic test.

\section{Genome Detection}

The most sensitive and specific diagnostic tool is reverse transcriptase polymerase chain reaction (RTPCR). However, it is not available as a diagnostic kit, therefore RNA extraction, reverse transcription and primer design vary from laboratory to laboratory. However, its use will detect very low numbers of rotavirus particles when not detectable by electron microscopy or antigen detection kits, and if $P$ and $G$ genotype-specific primers are used, will provide valuable epidemiological information. Polyacrylamide gel electrophoresis of RNA extracted from diarrhoeic stool provides an inexpensive and specific diagnostic tool. The 11 dsRNA segments of the genome are unique to rotavirus and comparison of electrophoretic patterns also gives epidemiological information. The whole procedure takes as little as $5 \mathrm{~h}$ and although less sensitive than RT-PCR, is equivalent to some antigen detection tests and electron microscopy [24].

\section{Antigen Detection}

The two main formats available are antigen capture ELISA and latex particle agglutination (LPA). In general, the former is more sensitive and specific than LPA. LPA has the advantage that it is cheaper and can be used as a rapid "one-off" test, whereas the ELISA 
format is better adapted to batch testing. It is possible, depending on the specificity of the antibodies used, for the tests to miss group $\mathrm{B}$ and $\mathrm{C}$ rotavirus infections.

\section{Treatment and Prevention}

There are no specific anti-rotaviral drugs and in most cases (even in HIV-infected children), the infection is self-limiting. The most important therapeutic intervention is to assess the degree of dehydration and institute oral or intravenous rehydration therapy as appropriate. Adjuncts to therapy include the administration of immunoglobulin orally [25,26] and the use of probiotics such as Lactobacillus casei spp. rhamnosus (strain GG), or Bifidobacterium bifidum [27]. Sources of immunoglobulin have included bovine colostrum, pooled human gamma-globulin fractions or hyperimmunised chicken egg yolk immunoglobulin (IgY). Each has worked well in decreasing the duration and frequency of diarrhoea, and oral immunoglobulin was used successfully to treat severe rotavirus diarrhoea in two bone marrow transplant recipients. Probiotic administration has a similar efficacy but has the added advantage of enhancing the specific immune response to rotavirus. Neither intervention has been tried in HIV-infected individuals.

Active immunisation against rotavirus infection has been an important goal for many years, which was almost realised in 1998 [14]. Both bovine and simian rotaviruses have been used following "Jennerian" principles (i.e. analogous to using cowpox to prevent smallpox), to protect against rotavirus infection. Both worked well (ca. $80 \%$ protection) in trials in Europe and the USA, but when used in developing countries in Africa and South America where they would have had greatest impact, they were far less efficacious. Thus reassortant vaccines were developed which had 10 dsRNA genomic segments of either simian (rhesus) or bovine rotavirus with the remaining segment encoding VP7 being replaced by that from a human rotavirus. Quadrivalent reassortant rhesus rotavirus vaccine incorporating $\mathrm{VP}_{7}$ genomic segments expressing $G_{1}, G_{2}, G_{3}$ and $G_{4}$ proved to be the most effective in trials in the USA, Europe and most importantly in South America. In 1998, following a cost effectiveness analysis which showed benefit, the quadrivalent vaccine was introduced into routine use in infants in the USA. From September 1998 until July 1999, an estimated 1.5 million doses were given to 800,000 infants (ca. $25 \%$ of the birth cohort). During this time, there were 15 cases of intussusception occurring in infants who had received the vaccine reported to the Vaccine Adverse Events Reporting
System (VAERS) in the USA. A case-controlled study estimated an incidence of one case of intussusception for every 4,670 to 9,474 vaccinees [28], and the vaccine was withdrawn from use. Subsequently, a number of authors have disagreed with the association and have suggested that its use would still be very beneficial in developing countries where there is the highest rotavirus disease and mortality burden.

Nevertheless, despite this setback there are a number of new vaccines in production. These include a multivalent human bovine reassortant vaccine, a monovalent $\left(\mathrm{G}_{1}\right)$ human rotavirus vaccine and a monovalent lamb rotavirus vaccine which has already been licensed in China [29]. However, as yet, there have been no trials giving any oral rotavirus vaccine to HIV-infected children. Since wild rotavirus infection is no more severe in HIV-infected than HIV-uninfected infants and induces a brisk serological response in both, such vaccines should be safe and effective [30]. They should, however, not be given to those with overt AIDS.

\section{Adenovirus 40/41}

Adenoviruses have been detected in stool samples from patients with and without diarrhoeal disease. However, only adenovirus types 40 and 41 which are difficult to establish in culture have been firmly associated with diarrhoeal disease [1].

\section{Virology}

The family Adenoviridae comprises two major genera, Mastadenoviruses and Aviadenoviruses. The former are mammalian pathogens. All have nonenveloped virion particles with icosahedral symmetry from 60-90 $\mathrm{nm}$ in diameter (Fig. 6). They are eas-

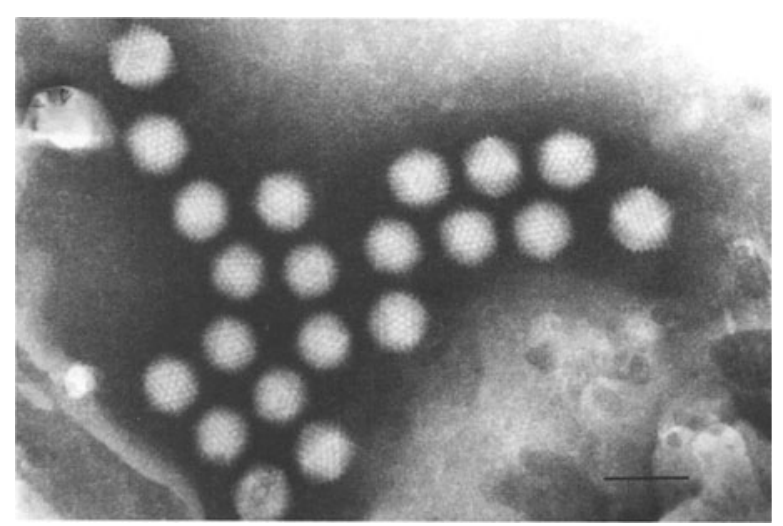

Fig. 6. A negative stain electron micrograph of faeces showing a cluster of typical adenovirus particles. Bar, $100 \mathrm{~nm}$ 
ily recognisable on electron microscopy. Adenovirus has a linear double-stranded DNA genome from 30 to $38 \mathrm{kbp}$ (kilobase pairs) long. There are at least 51 different human adenoviruses but only those in subgenus $\mathrm{F}$ (adenoviruses 40/41) cause diarrhoeal disease. Other adenoviruses, in particular some in subgenera B2 (e.g. types 11 and 50) and D (e.g. types 9, 20, 22, 23, 43-49), are excreted by HIV-infected patients but rarely by HIV non-infected individuals [31]. Although in most instances infection is asymptomatic, in some AIDS patients these viruses can cause hepatitis and colitis (as well as pnemonitis, nephritis and encephalitis) [32]. Except for subgenus F, adenoviruses are easily grown in a variety of cell culture lines and produce cytopathic effects.

\section{Epidemiology, Pathogenesis and Immunity}

In most surveys, adenovirus $40 / 41$ is the second commonest cause of viral diarrhoea in hospitalised children, being responsible for $0.9 \%-11 \%$ of cases. However, serosurveys indicate that by the age of 3 years between $30 \%$ and $100 \%$ of children have neutralising anti-adenovirus $40 / 41$ antibodies. It is also a minor cause of travellers' diarrhoea. However, there are preliminary data to suggest that previous infection does not provide protection against subsequent symptomatic re-infection [33]. Infection is spread by the faeco-oral route but food-borne or water-borne spread has not been described. There is no particular seasonality to infection with adenovirus $40 / 41$. How it causes diarrhoea is not known, nor is much known on immunity to infection. However, in HIV-infected patients who are infected with subgenus $D$ adenoviruses, there is evidence of impaired production of neutralising antibody against homologous virus [32].

\section{Diagnosis, Management and Prevention}

Adenovirus can be visualised easily on direct negative stain microscopy of faeces (Fig. 6). However, since a number of different adenoviruses can be excreted in stool, this does not prove that adenovirus is the aetiological agent. Immunoelectron microscopy using anti-adenovirus $40 / 41$ antisera will help, and clumped virus particles should be seen. There are commercially available ELISA-based kits for the diagnosis of adenovirus 40/41 diarrhoea which appear highly sensitive and specific. There have been some indications that the current commercial kits are less efficient at detecting South African strains [34]. PCR-based techniques are available but not in kit form.

There is no specific therapy and management involves assessment of dehydration with appropriate rehydration. There are no vaccines for prevention of adenovirus $40 / 41$ infection although a vaccine for other adenoviruses has been used to prevent infection in military recruits in the USA.

\section{Astrovirus}

Astroviruses were first described by Madeley and Cosgrove in 1975 when stools of infants with gastroenteritis were examined by electron microscopy (Fig. 7). They are named for their distinctive appearance on electron microscopy, namely, a smooth outer electron-dense shell with an inner 5- or 6pointed negatively staining star-shaped core (astron is Greek for a star). Subsequently, human transmission experiments confirmed their role as viral enteropathogens and strains of astrovirus were established in artificial culture.

\section{Virology}

Astroviruses are small $(28-34 \mathrm{~nm})$, round unenveloped RNA viruses within the family Astroviridae. Their genome is positive-sense, unsegmented, linear single-stranded RNA of approximately $6.8 \mathrm{~kb}$. It comprises three open reading frames (ORF). ORF ia and ORF $1 \mathrm{~b}$ encode non-structural proteins including a serine protease, RNA-dependent RNA polymerase and a nuclear localisation signal. ORF2 encodes a putative $90-\mathrm{kDa}$ polyprotein that is cleaved by the viral serine protease into three to five structural proteins that make up the capsid. Astroviruses can be grown in the presence of trypsin on primary human fetal cells or more conveniently $\mathrm{CaCo} 2$ cells, but can require repeated blind passage. There are at least eight serotypes of human astrovirus. Astroviruses are

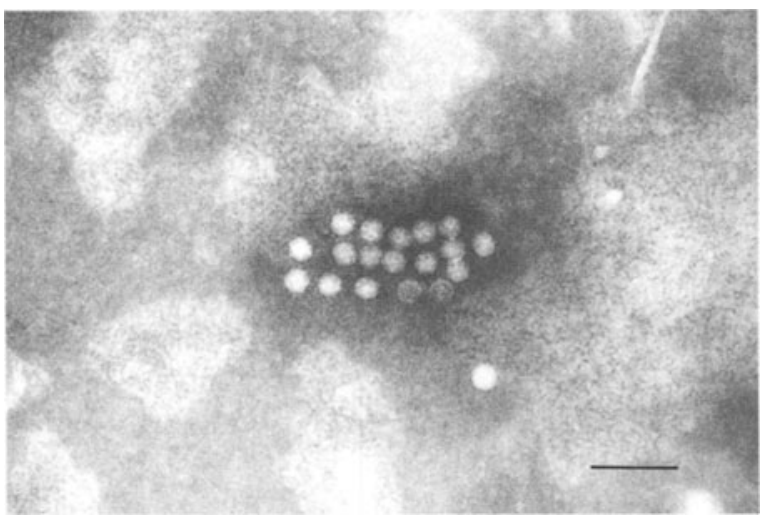

Fig. 7. A negative stain electron micrograph of faeces from a child with astrovirus diarrhoea. Bar, $50 \mathrm{~nm}$ 
also a cause of diarrhoeal disease in a number of other animal species including birds, cats, dogs, sheep and cattle and there is some evidence of crossspecies transmission. Astroviruses survived for 5-6 days when dried at $20^{\circ} \mathrm{C}$ in faecal material onto porous or non-porous material. Survival was significantly longer at $4^{\circ} \mathrm{C}[35]$. This was equivalent to survival of adenovirus but less than that of rotavirus.

\section{Epidemiology and Pathogenesis}

Infection is acquired by the faeco-oral route, but the infective dose is not established. Although astrovirus is primarily a cause of childhood gastro-enteritis, it can cause outbreaks in adults especially with the less common serotypes [1]. It is responsible for $2 \%-11 \%$ of childhood cases of gastro-enteritis in hospitalised patients, but in up to $20 \%$ of those in communitybased studies, thus reflecting its lesser severity compared to rotavirus [36-38]. In temperate countries, the peak of infection is in winter usually a month or so before the rotavirus peak. Although serotype 1 is most often implicated in any season, many serotypes co-circulate [39]. Food-borne outbreaks have also been described most often due to the rarer serotypes [40]. Over $90 \%$ of children in developed countries have antiastrovirus antibodies by 9 years of age [41]. Astrovirus has a world-wide distribution being found in every country where it has been sought. In some studies astrovirus has been identified as a significant cause of chronic diarrhoea [42], for example, in a longitudinal study of HIV-infected adults in the USA [43]. However, no such association was found in smaller studies of HIV-infected children and adults $[44,45]$. Prolonged excretion of astroviruses has been detected in immunodeficient and immunosuppressed patients [46]. Apart from this, little is known about immunity to infection, or how astrovirus produces diarrhoeal disease.

\section{Diagnosis}

Although electron microscopy was the tool first used for diagnosis, it is less sensitive than either the commercially available ELISAs or RT-PCR. RT-PCR based on conserved regions of the protease gene in ORF 1a is the most sensitive diagnostic tool but this is an "in-house" assay.

\section{Treatment and Prevention}

There are no specific antiviral drugs and the management is that of dehydration. There is no vaccine for prevention of infection.

\section{Caliciviruses}

In 1968, there was an outbreak of gastro-enteritis in teachers and pupils in a school in Norwalk, Ohio, USA. It was predominantly a vomiting disease and was termed winter vomiting disease. It was shown to be transmissible to volunteers by ultrafiltrates of stool and to be ether- and relatively heat-stable, but could not be established in cell or organ culture. In 1972, 27$\mathrm{nm}$ viral particles were seen by immune electron microscopy using convalescent sera from one of the volunteers for the transmission experiment. The agent was called Norwalk virus and similar outbreaks of infection with similar small round-structured viruses (SRSV) were described elsewhere. In 1976, Madeley and Cosgrove detected calicivirus particles in diarrhoeic stools of children and subsequently similar caliciviruses were associated with outbreaks of infection. Eventually, it became clear that both the SRSVs and caliciviruses were genomically similar and both were assigned to the family Caliciviridae [47] in which there are two other genera (Vesivirus, feline calicivirus and Lagovirus, rabbit haemorrhagic disease virus).

\section{Virology}

The human caliciviruses comprise two genera Norwalk-like (NLV, previously SRSV) and Sapporo-like (SLV, previously classical caliciviruses) viruses, and viruses related to these genera can also infect pigs and cattle. Caliciviruses are small $(23-32 \mathrm{~nm})$ round unenveloped RNA viruses. Their genomes are singlestranded, linear, unsegmented positive-sense RNA. The genome is polyadenylated and approximately $7.6 \mathrm{~kb}$ in length. The genome of NLVs is divided into three ORFs. The first ORF encodes a polyprotein with motifs similar to helicase, cysteine proteinase and RNA-dependent RNA polymerase proteins of picornaviruses. ORF2 encodes the capsid protein and $\mathrm{ORF}_{3}$ encodes a small basic protein of unknown function. The SLV genome differs in that ORF1 encodes both the non-structural and capsid proteins, $\mathrm{ORF}_{2}$ is similar to $\mathrm{ORF}_{3}$ of NLV and $\mathrm{ORF}_{3}$ encodes another small basic protein of unknown function. On electron microscopy, NLVs have an indistinct feathery edge and amorphous substructure (Fig. 8). SLVs have a much more distinct structure. The major structural protein folds into 90 dimers and assembles in an icosehedral form but with 32 cup-shaped depressions (calyx is Greek for a cup), which impart the characteristic "Star of David" appearance on electron microscopy (Fig. 9). Based on RNA sequences of the RNA polymerase or capsid genes, the NLVs can be subdivided into two genogroups but the SLVs are more homogeneous. 


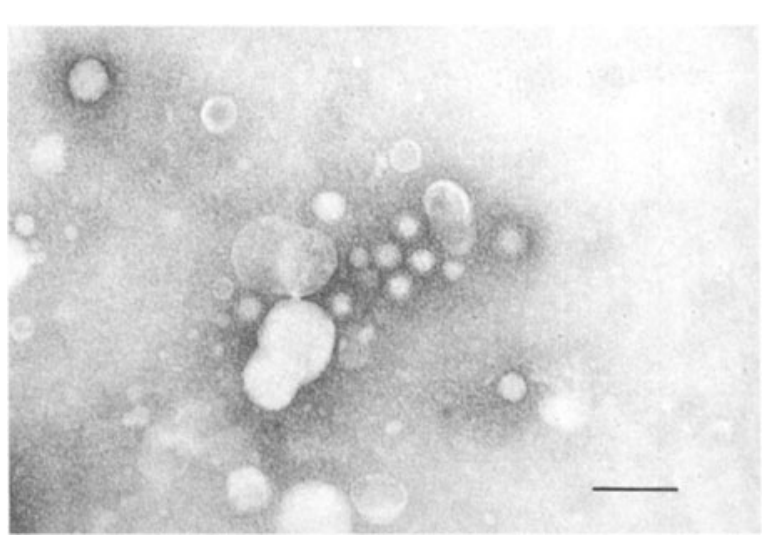

Fig. 8. A negative stain electron micrograph of Norwalk virus (previously termed small round structured virus). Bar, $50 \mathrm{~nm}$

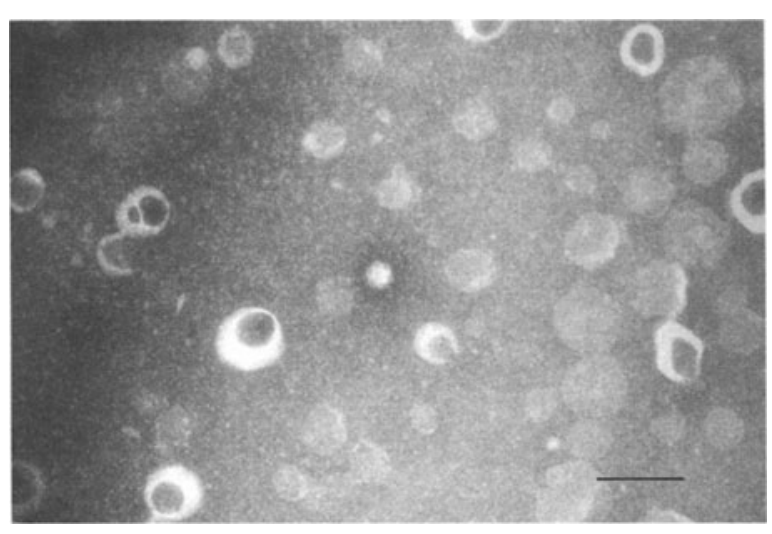

Fig. 9. Negative stain electron micrograph of Sapporo virus showing the "Star of David" shape typical of classical calicivirus. Bar, $50 \mathrm{~nm}$

Calicivirus is currently species infected/virus genus/virus name/strain designation/year of isolation/country of isolation. Thus Norwalk virus is $\mathrm{Hu} / \mathrm{NLV} /$ Norwalk virus/8FIIA/1968/US and Sapporo virus is $\mathrm{Hu} / \mathrm{SLV} / \mathrm{Sapporo}$ virus/1982/JA [48, 49]. However, common names are easier to cope with (Table 3). With increasing detection, more new human caliciviruses are being described.

\section{Epidemiology, Pathogenesis and Immunity}

The caliciviruses have a worldwide distribution. Some have been detected only in one geographical region but others have been found over the same period in eight countries on five continents [50]. Infections occur sporadically, as community-wide epidemics or as food-borne epidemics [51]. No particular seasonal distribution is evident for SLVs, but
Table 3. The human calicivirus

$\begin{array}{ll}\text { Norwalk-like viruses } & \\ \text { Genogroup I } & \begin{array}{l}\text { Norwalk virus } \\ \text { Southampton virus } \\ \text { Desert Shield virus } \\ \text { Cruise Ship virus }\end{array} \\ & \text { Snow Mountain Agent } \\ & \text { Hawaii virus } \\ \text { Gexico virus } \\ \text { Toronto virus } \\ \text { Lordsdale virus } \\ \text { Grimsby virus } \\ \text { Gwynedd virus } \\ & \text { White River virus } \\ & \text { Camberwell virus } \\ & \text { Melksham virus } \\ & \text { Sapporo virus } \\ & \text { Manchester virus } \\ & \text { Parkville virus } \\ & \text { London virus } \\ & \text { Plymouth virus } \\ & \text { Houston virus }\end{array}$

in temperate countries NLVs are more prominent in winter. The seroprevalence of calicivirus infection varies by age, virus group and geographical region. For example, in Kenya approximately $60 \%$ of adults have antibody to genogroup I NLV (Norwalk virus), $80 \%$ to SLV and $100 \%$ to genogroup II NLV (Mexico virus), whereas in Japan and parts of Southeast Asia, $82 \%-88 \%$ of adults were seropositive to Mexico virus $[52,53]$. In terms of the relative importance of calicivirus in causing paediatric gastro-enteritis, a study in Finland found that of 832 children aged 2 months to 2 years, $20 \%$ of cases of diarrhoeal disease were due to NLVs and $9 \%$ to SLVs. In comparison, astroviruses were found in $10 \%$ of children, enteric adenoviruses in $6 \%$ and rotavirus in $31 \%$ [54]. Transmission can occur directly by the faecooral route or even via aerosols produced by projectile vomiting. Person-to-person transmission has occurred prior to symptomatic disease and contact while playing American football [55, 56]. Food-borne and water-borne outbreaks are not uncommon. Foodstuff implicated as vehicles includes shellfish such as oysters which concentrate human excreta in water, raspberries sprayed with human excreta and even food contaminated by presymptomatic foodhandlers $[51,55]$. The infective dose is low $(<100$ particles) and there can be prolonged asymptomatic shedding of virus. In addition, the caliciviruses are quite stable (to $100 \mathrm{ppm}$ chlorine, freezing and heating to $60^{\circ} \mathrm{C}$ ). The incubation period is $1-2$ days, and 
Fig. 10. Examples of primers used for the detection of human calicivirus from faeces

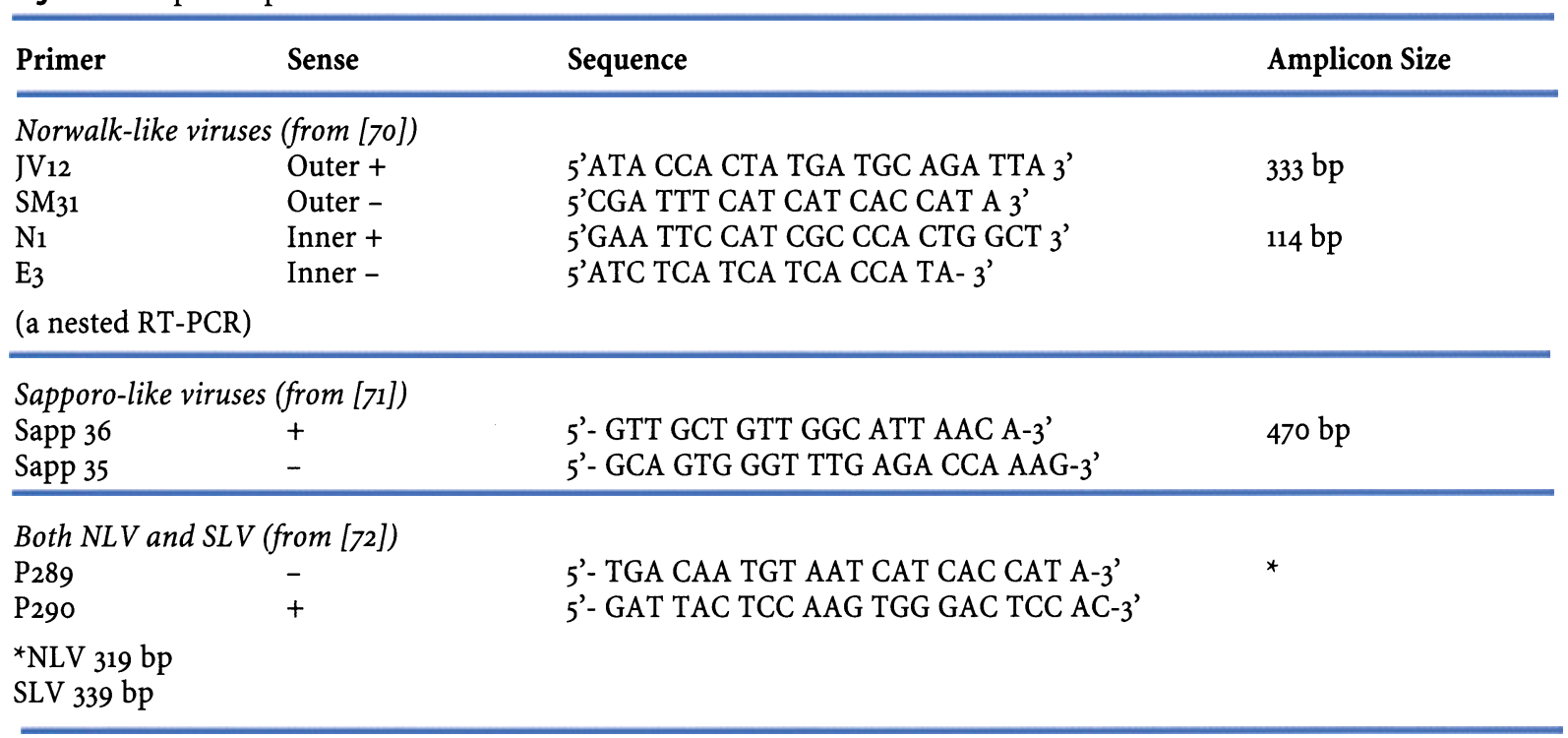

in general the NLVs produce a predominantly vomiting illness with only $30 \%$ also having diarrhoea, whereas the SLVs produce predominantly diarrhoea with some vomiting. The illness is usually shortlived (2-3 days) but in volunteer studies, excretion of NLVs persisted for up to 2 weeks [57].

Following infection there is a homotypic antibody response to the infecting virus but this does not necessarily persist. Repeat symptomatic infections can occur in volunteers after re-challenge and childhood exposure does not protect adults from disease [58]. In addition, there is great diversity in the calicivirus strains that infect humans [59]. There is very little information on calicivirus infection in immunocompromised hosts or those infected with HIV.

\section{Diagnosis}

Although these viruses were first discovered by electron microscopy this is a relatively insensitive diagnostic tool, except in the first few days of gastroenteritis [48]. Some antigen detection tests are available using ELISA or radio-immuno-assay formats but they are not able to detect all caliciviruses. RTPCR is the most sensitive diagnostic tool but no single primer set will detect all viruses (Fig. 10). None of the tests are commercially available.

\section{Treatment and Prevention}

There are no vaccines available for prevention of infection.

\section{Other Viruses}

For the remaining viruses, either their causative role in diarrhoeal disease is not entirely proven or they are responsible for a minority of cases.

\section{Coronavirus}

Coronaviruses are enveloped pleomorphic viruses, 60-200 $\mathrm{nm}$ in diameter, which have characteristic club-shaped glycoprotein spikes protruding from their surface (Fig. 11). The genome is single-stranded positive-sense RNA of $27-32 \mathrm{~kb}$ in size. Although coronaviruses have been isolated from diarrhoeic stool [60], they are found on electron microscopy as

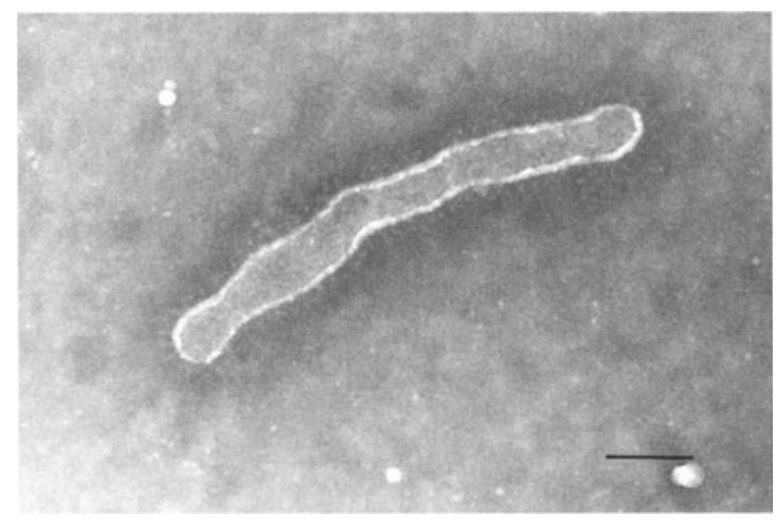

Fig. 11. Negative stain electron micrograph of a coronavirus from stool. Bar, $100 \mathrm{~nm}$ 


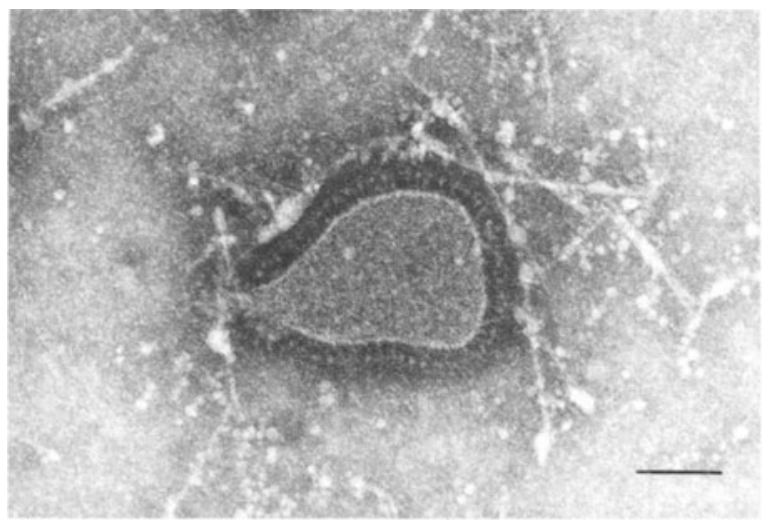

Fig. 12. Negative stain electron micrograph of a torovirus from the stool of a child with gastro-enteritis. Bar, $100 \mathrm{~nm}$

frequently from controls as from patients with gastro-enteritis. The diagnosis is based entirely on negative stain electron microscopy. Virus culture is lengthy and there are no antigen detection or genomic-based diagnostic methods.

\section{Torovirus}

Toroviruses are members of the family Coronaviridae and are enveloped with a fringe of glycoprotein spikes (Fig. 12). They are 100-140 nm in diameter and have a tightly coiled tubular nucleocapsid that assumes the shape of a toroid (doughnut shape). This gives them the name torovirus [61]. Their genome is single-stranded positive-sense linear RNA of over $20 \mathrm{~kb}$ in size. They were first recognised as causes of diarrhoea in cattle (Breda virus) and horses (Berne virus). Toroviruses are found in $3 \%-35 \%$ of samples from children with gastro-enteritis. Torovirus infection was detected more frequently in immunocompromised and nosocomially infected children in one survey, while in another it was found as frequently in those over 3 years as in those under $3[62,63]$.

Diagnosis is by negative stain electron microscopy of faecal suspensions, where characteristic spherical or kidney-shaped fringed virus particles are seen (Fig. 12). Immunoelectron microscopy has also been used with animal antisera. A human torovirus has been maintained in artificial culture, but this is not a realistic diagnostic method.

\section{Pestivirus}

Pestiviruses are a genus within the family Flaviviri$d a e$ and are related to hepatitis $C$ virus. They are enveloped viruses some $40-60 \mathrm{~nm}$ in diameter with

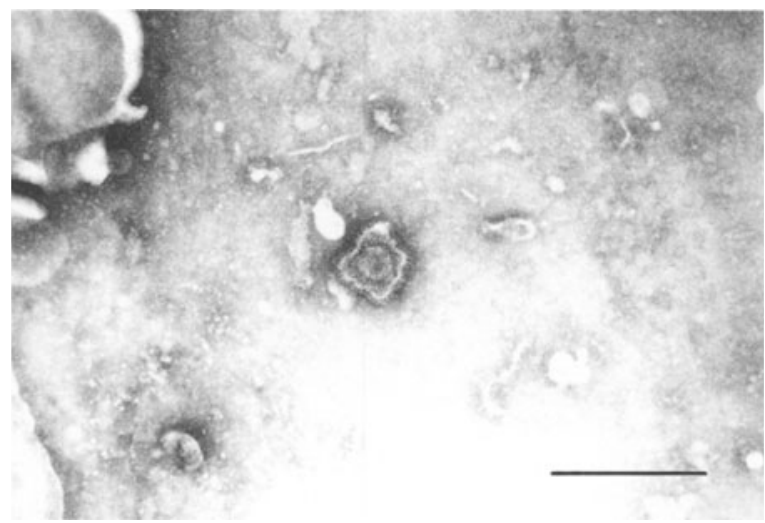

Fig. 13. A pestivirus in the stool of a case of childhood gastro-enteritis. Bar, $100 \mathrm{~nm}$

an external glycoprotein fringe (Fig. 13). Their genome is single-stranded positive-sense RNA approximately $11-12 \mathrm{~kb}$ in length. Bovine diarrhoea virus (BDV) is a pestivirus and a survey of 128 children with diarrhoea detected BDV antigens in 30 $(23 \%)$ of these [64]. A slightly greater proportion of HIV-seropositive patients with chronic diarrhoea (17.8\%) were BDV seropositive compared to HIVinfected patients without diarrhoea (15.2\%) in a Zambian study [65].

Diagnosis is by antigen detection using monoclonal anti-BDV antibodies, although virus can rarely be seen on direct negative stain electron microscopy of stool (Fig. 13).

\section{Picobirnavirus}

Picobirnaviruses (and Picotrirnaviruses) are a novel group of viruses tentatively included within the family Birnaviridae [66]. They are small $(30-40 \mathrm{~nm}$ diameter) unenveloped viruses with icosahedral symmetry. Their genome is double-stranded linear bi- or tri-segmented RNA with segment lengths of 2.6 and $1.9 \mathrm{kbp}$ for picobirnaviruses and 2.9, 2.4 and $0.9 \mathrm{kbp}$ for picotrirnaviruses.

Picobirnaviruses have been described in association with childhood gastro-enteritis and outbreaks of gastro-enteritis in elderly care facilities but their pathogenic role is not entirely clear. They have been strongly associated with diarrhoea in HIV-infected patients in Argentina, but similar studies in HIVinfected adults or children in Venezuela did not confirm this association $[43-45,67,68]$.

Diagnosis is by polyacrylamide gel electrophoresis of RNA extracted from faeces. Characteristic bands (2 or 3) of the correct molecular mass range demonstrate the presence of virus. Recently, an RT-PCR has been 
developed which should be more sensitive [69]. There are no commercially available kits for detection.

\section{References}

1. Hart CA, Cunliffe NA (1999) Viral gastroenteritis. Curr Opin Infect Dis 12:447-457

2. Bishop RF, Davidson GP, Holmes IH, Ruck BJ (1973) Virus particles from children with viral gastroenteritis. Lancet i:1281-1283

3. Burns NW, Sidat-Pajouh M, Krishnaney AA, Greenberg HB (1996) Protective effect of rotavirus VP6-specific IgA monoclonal antibodies that lack neutralizing activity. Science 272:104-107

4. Riepenhaff-Talty SM, Morse K, Wang CH, et al (1997) Epidemiology of group $\mathrm{C}$ rotavirus infection in western New York women of child-bearing age. J Clin Microbiol 35:486-488

5. Cunliffe NA, Dove W, Jiang B, et al (2001) Detection of group $C$ rotavirus in children with acute gastroenteritis in Blantyre, Malawi. Pediatr Infect Dis J 20:1088-1190

6. Krishnan T, Sen A, Sinha J, et al (1999) Emergence of adult diarrhoea rotavirus in Calcutta, India. Lancet 353:380-381

7. Cunliffe NA, Bresee JS, Gentsch JR, et al (2002) The expanding diversity of rotaviruses. Lancet 359:640-642

8. Gentsch JR, Woods PA, Ramachandran M, et al (1996) Review of $G$ and $P$ typing results from a global collection rotavirus strains: implications for vaccine development. J Infect Dis 174:S30-S36

9. Gouvea V, de Castro L, Timenetsky M, et al (1994) Rotavirus serotype $\mathrm{G}_{5}$ associated with diarrhea in Brazilian children. J Clin Microbiol 32:1408-1409

10. Cunliffe NA, Gondwe JS, Graham SM, et al (2001) Rotavirus strain diversity in Blantyre Malawi from 1997 to 1999; J Clin Microbiol 39:836-843

11. Abah MA, Rohwedder A, Olaleye OD, Werchau H (1997) Nigerican rotavirus G8 could not be typed by PCR due to nucleotide mutation at the 3 ' end of the primer binding site. Arch Virol 142:1881-1887

12. Ramachandran $M$, Kirkwood CD, Unicomb L, et al (2000) Molecular characterization of serotype G9 rotavirus strains from a global collection. Virology 278:436-444

13. Cunliffe NA, Dove W, Bunn JEG, et al (2001) Expanding global distribution of rotavirus serotype G9: detection in Libya, Kenya and Cuba. Emerg Infect Dis 7:890-892

14. Lynch M, Bresee JS, Gentsch JR, Glass RI (2000) Rotavirus vaccines. Curr Opin Infect Dis 13:495-502

15. Cunliffe NA, Kilgore PE, Bresee JS, et al (1998) Epidemiology of rotavirus diarrhoea in Africa: a review to assess the need for rotavirus immunization. Bull WHO 76:525-537

16. Batt RM, Embaye H, van de Waal S, et al (1995) Application of organ culture of small intestine to the investigation of enterocyte damage by equine rotavirus. J Pediatr Gastroenterol Nutr 20:326-332

17. Jourdan N, Brunet JP, Sapia C, et al (1998) Rotavirus infection reduces sucrase-isomaltase expression in human intestinal epithelial cells by perturbing protein targetting and organisation of microvillar cytoskeleton. J Virol 72:7228-7236

18. Perez JF, Chemello MC, Kiprandi F, et al (1998) Oncosis in MA 104 cells is induced by rotavirus infection through an increase in intracellular $\mathrm{Ca}^{2+}$ concentrations. Virology 252:17-27

19. Lundgren O, Svensson L (2001) Pathogenesis of rotavirus diarrhea. Microbes Infect 3:1145-1166

20. Ball JM, Jian P, Zeng CQ-Y et al (1996) Age dependent diarrhea induced by a rotaviral non-structural protein. Science 272:101-104

21. Franco MA, Greenberg HB (1995) Role of B-cells and cytotoxic T-lymphocytes in clearance of and immunity to rotavirus in mice. J Virol 69:7800-7806

22. Velazquez FR, Matson DO, Calva JJ, et al (1996) Rotavirus infection in infants as protection against subsequent infection. New Engl J Med 335:1022-1028

23. Yuan L, Ward LA, Rosen BI, et al (1996) Systemic and intestinal antibody secreting cell responses and correlates of protective immunity to human rotavirus in a gnotobiotic pig model of disease. J Virol 70:3075-3081

24. Ibrahim OS, Sunderland D, Hart CA (1990) Comparison of four methods for detection of rotavirus in faeces. Trop Doct 20:30-32

25. Hammarstrom L (1999) Passive immunity against rotavirus in infants. Acta paediatr 88 [Suppl]:127-132

26. Sarker SA, Casswall TH, Juneja LR, et al (2001) Randomized, placebo-controlled, clinical trial of hyperimmunized chicken egg yolk immunoglobulin in children with rotavirus diarrhea. J Pediatr Gastroenterol Nutr 32:19-25

27. Szajewska H, Mrukowicz JZ (2001) Probiotics in the treatment of prevention of acute infectious diarrhea in infants and children: a systematic review of published randomized, double-blind, placebo-controlled trials. J Pediatr Gastroenterol Nutr 33:S17-S25

28. Murphy TV, Garguillo PM, Massoudi MS, et al (2001) Intussusception among infants given oral rotavirus vaccine. New Engl J Med 334:564-572

29. Cunliffe NA, Bresee JS, Hart CA (2002) Rotavirus vaccines: development, current issues and future prospects. J Infect. (in press)

30. Cunliffe NA, Gondwe JS, Kirkwood CD, et al (2001) Effect of concomitant HIV infection on presentation and outcome of rotavirus gastroenteritis in Malawian children. Lancet 358:550-555

31. De Jong JC, Wermenbol AG, Verweij-Uijterwaal MW, et al (1999) Adenovirus from human immunodeficiency virus-infected individuals including two strains that represent new candidate serotypes Ad50 and $A_{51}$ of species $B_{1}$ and $D$ respectively. J Clin Microbiol 37:3940-3945

32. Lord A, Bailey AS, Klapper PE, et al (2000) Impaired humoral responses to subgenus $\mathrm{D}$ adenovirus infections in HIV-positive patients. J Med Virol 62:405-409

33. Unicomb LE, Jareckikhan K, Hall A, Podder G (1996) Previous enteric adenovirus infection does not protect against subsequent symptomatic infection: longitudinal follow-up of 8 infants. Microbiol Immunol 40:161-168

34. Moore PL, Steele AD, Alexander JJ (2000) Relevance 
of commercial diagnostic tests to detection of enteric adenovirus infections in South Africa. J Clin Microbiol 38:1661-1663

35. Abad FX, Villena C, Guix S, et al (2001) Potential role of fomites in vehicular transmission of human astroviruses. Appl Env Microbiol 67:3904-3907

36. Herrmann JE, Taylor BN, Echeverria P, Blacklow NR (1991) Astroviruses as a cause of gastroenteritis in children. New Engl J Med 324:1757-1760

37. Maldonaldo Y, Cantwell M, Old M, et al (1998) Population-based prevalence of symptomatic and asymptomatic astrovirus infection in rural Mayan infants. J Infect Dis 178:334-339

38. Cunliffe NA, Dove W, Gondwe JS, et al (2002) Detection and characterization of human astroviruses in children with acute gastroenteritis in Blantyre, Malawi. J Med Virol 67:563-566

39. Guix S, Caballero S, Villena C, et al (2002) Molecular epidemiology of astrovirus infection in Barcelona, Spain. J Clin Microbiol 40:133-139

40. Walter JE, Mitchell DK (2000) Role of astroviruses in childhood diarrhea. Curr Opin Pediatr 12:275-279

41. Koopmans MPG, Bijen MHL, Monroe SS, Vinje J (1998) Age-stratified seroprevalence of neutralizing antibodies to astrovirus types 1 to 7 in humans in the Netherlands. Clin Diagn Lab Immunol 5:33-37

42. Unicomb LE, Banu NN, Azim T, et al (1998) Astrovirus in association with acute, persistent and nosocomial diarrhea in Bangladesh. Pediatr Infect Dis J 17:611-614

43. Grohmann GS, Glass RI, Pereira WG, et al (1993) Enteric viruses and diarrhea in HIV-infected patients. New Engl J Med 329:14-20

44. Gonzalez GG, Pinjol FH, Liprandi F, et al (1993) prevalence of enteric viruses in human immunodeficiency virus seropositive patients in Venezuela. J Med Virol 55:288-292

45. Liste MB, Natera I, Suarez JA, et al (2000) Enteric virus infections and diarrhea in healthy and human immunodeficiency virus-infected children. J Clin Microbiol 38:2873-2877

46. Cox GJ, Matsui SM, Lo RS, et al (1994) Etiology and outcome of diarrhea after marrow transplantation: a prospective study. Gastroenterol 107:1398-1407

47. Clarke IN, Lambden PR (1997) The molecular biology of caliciviruses. J Gen Virol 78:291-301

48. Atmar RL, Estes MK (2001) Diagnosis of noncultivable gastroenteritis viruses, the human caliciviruses. Clin Microbiol Rev 14:15-37

49. Green KY, Ando T, Balayan MS, et al (2000) Taxonomy of the caliciviruses. J Infect Dis 181 [Suppl 2]:S322-S330

50. Noel JS, Fankhauser RL, Ando T, et al (1999) Identification of a distinct common strain of "Norwalk-like virus" having a global distribution. J Infect Dis 179:1334-1344

51. Glass RI, Noel J, Ando T, et al (2000) The epidemiology of enteric caliciviruses from humans: a reassessment using new diagnostics. J Infect Dis 181 [Suppl 2]:S254-S261

52. Nakata S, Honma S, Numata K, et al (1998) Prevalence of human calicivirus infections in Kenya as determined by enzyme immunoassays for three genogroups of virus. J Clin Microbiol 36:3160-3163
53. Honma S, Nakata S, Numata K, et al (1998) Epidemiological study of prevalence of genogroup II human calicivirus (Mexico virus) infections in Japan and Southeast Asia as determined by enzyme-linked immunosorbent assay. J Clin Microbiol 36:2481-2484

54. Pang X-L, Honma S, Jakata S, Vesikari T (2000) Human caliciviruses in acute gastroenteritis of young children in the community. J Infect Dis 181 [Suppl 2]:S288-S294

55. Gaulin C, Frigon M, Poirier D, Fournier C (1999) Transmission of calicivirus by a foodhandler in the presymptomatic phase of illness. Epidemiol Infect 123:475-478

56. Becker KM, Moe CL, Southwick KL, et al (2000) Transmission of Norwalk virus during a football game. New Engl J Med 343:1223-1227

57. Okhuysen PC, Jiang X, Ye L, et al (1995) Viral shedding and fecal IgA response after Norwalk virus infection. J Infect Dis 171:566-569

58. Matsui SM, Greenberg HB (2000) Immunity to calicivirus infection. J Infect Dis 181 [Suppl 2]:S331-S335

59. Gonin P, Couillard M, d'Halewyn M-A (2000) Genetic diversity and molecular epidemiology of Norwalklike viruses. J Infect Dis 181 [Suppl 2]:S691-S697

6o. Zang XM, Herbst W, Kousoulas KG, Storz J (1994) Biological and genetic characterization of a haemagglutinating coronavirus isolated from a diarrhoeic child. J Med Virol 44:152-161

61. Duckmanton L, Luan B, Devenish J, et al (1997) Characterization of torovirus from human fecal specimens. Virology 239:158-168

62. Jamieson FB, Wang EEL, Bain C, et al (1998) Human torovirus: a new nosocomial gastrointestinal pathogen. J Infect Dis 178:1263-1269

63. Waters V, Ford-Jones EL, Petric M, et al (2000) Etiology of community-acquired pediatric viral diarrhea. A prospective longitudinal study in hospitals, emergency departments, pediatric practices and child care centers during the winter rotavirus outbreak 1997 to 1998. Pediatr Infect Dis J 19:843-848

64. Yolken R, Dubovi E, Leister F, et al (1989) Infantile gastroenteritis associated with excretion of pestvirus antigens. Lancet i:517-520

65. Giangaspero M, Vacira M, Morgan D, et al (1993) Anti-bovine diarrhoea virus antibodies in adult Zambian patients infected with human immunodeficiency virus. Int J STD AIDS 4:300-302

66. Chandra R (1997) Picobirnavirus, a novel group of undescribed viruses of mammals and birds: a mini review. Acta Virol 41:59-62

67. Giordano MO, Martinez LC, Rinaldi D, et al (1998) Detection of picobirnavirus in HIV-infected patients with diarrhea in Argentina. J Acquir Immun Defic Syndr Hum Retrovirol 18:380-383

68. Giordano MO, Martinez LC, Rinaldi D, et al (1999) Diarrhea and enteric emerging viruses in HIV-infected patients. AIDS Res Hum Retroviruses 15:1427-1432

69. Rosen BI, Fang ZY, Glass RI, et al (2000) Cloning of human picobirnavirus genomic segments and development of an RT-PCR detection assay. Virology 277:316-329

70. O'Neill HJ, McCaughey C, Wyatt DE, et al (2001) Gastroenteritis outbreaks associated with Norwalk-like viruses and their investigation by nested RT-PCR. BMC 
Microbiol http://www.biomedcentral.com/1471-2180/ $1 / 14$

71. Berke T, Golding B, Jiang X, et al (1997) Phylogenetic analysis of caliciviruses. J Med Virol 52:419-424
72. Jiang X, Huang PW, Zhong WM, et al (1999) Design and evaluation of a primer pair that detects both Norwalk- and Sapporo-like caliciviruses by RT-PCR. J Virol Methods 83:145-154 